Zenovii-Mykhailo Zadorozhnyi,

D.Sc., Professor, Ternopil National Economic University, Ukraine

Valentyna Yasyshena,

Ph.D., Associate Professor, Ternopil National Economic University, Ukraine

\title{
INTANGIBLE ASSETS ACCOUNTING AND REPORTING ISSUES
}

Abstract. The article examines the views of foreign economists on the importance of the impact of intangible assets (IA) and goodwill on business. The main purpose of this study is to improve and develop approaches of accounting for IA and goodwill, reflecting them in the financial and management reporting. The systematization of literary sources and the study of regulatory documents showed that there were several problematic issues related to the accounting and reporting of IAs and goodwill that needed elaboration and clarification. The urgency of solving this scientific problem lies in the fact that due to the existence of unresolved issues in accounting for IA and goodwill, as well as the formation of indicators in the financial statements, there is a significant gap between the methodology of accounting for these assets and current requirements of the economy. It is proposed to amend the Methodological Provisions № 417 by allocating the IA into a separate group for more detailed state statistical observation of these assets. It is recommended to separate the subaccount for accounting software showing the detailed information for this subaccount in the Notes to the Annual Financial Statements. To reconcile goodwill with the Plan of Accounts and Reporting, it is offered to set out the title of Section 1 of the Notes to the Annual Financial Statement, as follows: «Intangible Assets and Goodwill». It is recommended to keep records of internal goodwill in managerial and financial accounting, with the separation of the subaccount, with amendments to Section 1 of the Notes to the Annual Financial Statements regarding the inclusion of additional line 095 «Internal Goodwill». For management accounting of IA and goodwill, it is proposed to use the form of internal management reporting, which is based on paragraph 5 «Notes to the Annual Financial Statements», which contains additional indicators that allow the management system to identify IA s both at the respective centres of responsibility and their units, for different periods, to control the amount, direction, deviation of the planned and actual expenses at the receipt of IA, etc. It is recommended to open an additional subaccount for accounting for IAs shortages with the disclosure in the Annex to Methodological Recommendations № 1327 of the procedure for accounting for IAs shortages using this subaccount. It is justified that the Management Report should be considered as a supplement to the financial statements. The management report proposes to disclose the information about the IA and, if available, about goodwill (internal goodwill), and to provide information aimed at the development of intellectual capital.

Keywords: brand, internal goodwill, management report, management report, identification, intellectual capital, intangible assets (IA), non-current assets, accounting, managerial reporting, financial reporting.

Introduction. The peculiarity of IAs is that they contribute to the growth of the business and, with a well-designed strategy, can generate a significant amount of profit for the future. Nowadays, there is a difference in foreign and domestic approaches to establishing the importance of using IA in the activities of economic entities. In domestic practice, one of the key reasons that make it impossible to analyse the status of IAs and their impact on the company's operations is that these assets are not properly displayed in the accounting and thereafter in the reporting. IAs are not fully reflected in the financial reporting of domestic companies, which accordingly reduces their share in comparison with other assets within the framework of the state statistical observation. This decreases the competitiveness of Ukrainian companies and does not contribute to the increase of their market value in the domestic and foreign markets. This situation necessitates research in improving the methodological approaches to accounting and reporting them.

Literature Review. Theoretical and methodological issues regarding the disclosure in accounting and reporting of information on $I A$ and determining their role in the activity of companies are considered in

Cite as: Zadorozhnyi, Z.-M., Yasyshena, V. (2019). Intangible Assets Accounting and Reporting Issues. Marketing and Management of Innovations, 4, 182-193. http://doi.org/10.21272/mmi.2019.4-15 
several scientific works of domestic and foreign scientists. Tearney (1973) points to the importance of disclosing goodwill components that create a company's profitability in business combinations. Ping and Bao (2014) emphasize the importance of goodwill assessment during the normal business period of a company. Delios and Beamish (2001) outline the prospects of IA's impact on international expansion and its success. Kaplan and Norton (2004) define the role of IA as a major source of sustainable value creation. Stewart (1997) emphasizes the problematic issues of not reflecting the company's intellectual capital. Travin (2010), Umantsiv (2006), Holov et al. (2013) substantiate the need to reflect in the account of «internal goodwill». Horovyi (2016) directs research to study the structure of IAs in different countries of the world and their impact on economic development.

However, despite the considerable expertise and high scientific level of publications on these issues, many aspects of the disclosure of IAs in accounting and financial reporting require elaboration and clarification. Highlighting unresolved issues previously. Today, there are several problematic issues related to the accounting and reporting of the IA that require further study, namely: non-disclosure of information about the IA in the framework of the state statistical observation; improvement of the software accounting and internal goodwill; inconsistency of goodwill in the Accounts plan and financial statements; insufficient development of issues regarding the reflection of IAs in management accounting and reporting; non-disclosure of IA shortages in accounting; the controversial issues of completing the Management Report and attributing it to the financial or management reporting. The purpose of the study is to improve and develop approaches to accounting for IA and to reflect them in the financial and management reporting, considering domestic and foreign experience.

Methodology and research methods. The theoretical and methodological basis of the study is the work of leading domestic and foreign scientists on the theory and methodology of accounting, management, legislative and normative acts on the organization of accounting and reporting. The methodology of the research is based on the study of the state of normative regulation of accounting of intangible assets and their reflection in the reporting through a critical analysis of regulatory documents of the database «Legislation of Ukraine» of Supreme Council of Ukraine. The table method was used to study the rankings of the world's best brands and to develop a report on intangible assets and goodwill according to the responsibility centres. The identification of problematic issues was determined through a quick survey and questionnaire of the chief accountants of the companies. The methods of comparison and grouping were used at all stages of the study, and the results were summarized at the final stage.

Results. The international consulting group (Interbrand, 2018) annually publishes the ranking of the world's most expensive brands. Brand assessment is based on several requirements, including the following: broad geographic coverage; publicity and awareness; brand operating profit; the ability of the brand to generate sustainable demand and profit in the future, etc. Global brands that are in the top ten in 2018 include brands listed in Table. 1.

From Table 1 you can see that today the intangible component plays a significant role in the value of the company and creates a significant gap between the book value and its market value. Globally, most economists also emphasize the importance of using IAs, emphasizing that their use has a significant impact on the economic benefits to the company of its value and economic development. Delios and Beamish (2001) outline the prospects for the impact of the IA on international expansion and its success. It should be noted that different companies which geographically diversify their business must adapt the existing benefits of intangible assets to be competitive in the new market environment.

In his research Stewart (1997) argues that accountants cannot measure a company's intellectual capital. And this hidden treasure today is what matters in society. Knowledge has replaced land, labour and capital as a contribution from knowledge-intensive companies. Therefore, to be aware of the impact of the IA on economic development, changes must be made, first and foremost, at the state level. 
Table 1. Top Global Brand Rankings 2018 (Top 10)

\begin{tabular}{|c|c|c|c|c|c|}
\hline Ranking & Brand & Country & Segment & $\begin{array}{c}\text { Change in brand value } \\
(2018 / 2017)\end{array}$ & $\begin{array}{c}\text { Brand value } \\
(\$ \mathrm{mln})\end{array}$ \\
\hline 1 & Apple & The USA & Technology & $+16 \%$ & 214,480 \\
\hline 2 & Google & The USA & Technology & $+10 \%$ & 155,506 \\
\hline 3 & Amazon & The USA & Retail & $+56 \%$ & 100,764 \\
\hline 4 & Microsoft & The USA & Technology & $+16 \%$ & 92,715 \\
\hline 5 & Coca-Cola & The USA & Beverages & $-5 \%$ & 66,341 \\
\hline 6 & Samsung & $\begin{array}{l}\text { South } \\
\text { Korea }\end{array}$ & Technology & $+6 \%$ & 59,890 \\
\hline 7 & Toyota & Japan & Automotive & $+6 \%$ & 53,404 \\
\hline 8 & $\begin{array}{l}\text { Mercedes- } \\
\text { Benz }\end{array}$ & Germany & Automotive & $+2 \%$ & 48,601 \\
\hline 9 & Facebook & The USA & Technology & $-6 \%$ & 45,168 \\
\hline 10 & McDonald's & The USA & $\begin{array}{c}\text { Restaurant } \\
\mathrm{s}\end{array}$ & $+5 \%$ & 43,417 \\
\hline
\end{tabular}

Sources: compiled by authors based on (Best global brands. Interbrand, 2018).

One of the problematic issues is the non-reflection of IAs within the framework of the state statistical observation. The Methodological Provisions on the Use of Financial Reporting for Statistics of Enterprises, approved by the State Statistics Committee Order of 31.12.2014 (hereinafter Methodological Provisions № 417), include the list of summarized indicators for non-current assets: unfinished capital investments; fixed assets and IA (residual value, original cost, depreciation); long-term biological assets (residual value); long-term financial investments; other non-current assets. In these Methodological Provisions, the IA is not separated into a separate group, but are combined with the Fixed Assets indicator, which reduces their value compared to other non-current assets and makes it impossible to conduct a comprehensive analysis of the IA to identify trends in their impact on the economy. This is a disadvantage that needs immediate removal.

The question is what can be learned about the national development of brands and compare them with the world ones if at the state level IA is not even separated into a separate group?

We must agree with Horovyi (2016), who noted that «unfortunately, according to the statistical reporting in Ukraine, the structure of the IA (unlike the structure of fixed or current assets) at the macro level is not kept. An approximate estimate can only be obtained by the structure of innovation costs in the economy (software - 81\%; external research - 15\%; other - 4\%; copyrights and licenses - 0 )».

Software, including computer programs, is one of the main components of IAs in the activities of economic entities because they occupy a significant proportion in the structure of these assets. When setting software on the balance sheet of an enterprise, it is necessary to consider several features that will ensure the use of this asset within the current legislation. Firstly, it is necessary to consider the existence and compliance of the supporting documents for the right of use or ownership of the software. Secondly, the degree of identification should be determined. In accordance with paragraph 12 of IAS 38, an asset is identified if it can be separated (alienated) or removed from an entity, it can be sold, transferred, licensed, leased or exchanged individually or in conjunction with it contract, identified asset or liability. Thirdly, it is necessary to establish the likelihood of obtaining future economic benefits associated with the use of the software and whether its value can be reliably determined, as referred to in paragraph 6 of PAS 8 . Paragraph 17 of IAS 38 prescribes exactly how to interpret «future economic benefits». Obtaining future economic benefits from the IA is predictive, and the usefulness of using the IA can be established in the process of supply, production, sale of products, management. 
Fourthly, when establishing a balance of the IA, it is necessary to determine to which group the software can be assigned, for example, an operating system for a computer without which it cannot work will be included in the cost of the computer and accounted with it according to from PAS 7 «Fixed Assets». Unlike accounting and enterprise management programs will be part of the IA group, as they are not an integral part of the computer and can work without them.

Therefore, there is a need to separate subaccounts for the accounting of computer programs. Account Plan 12 for Intangible Assets lacks a subaccount 126 that can be used for the accounting software (computer programs, software for electronic computers). According to the Notes to the Annual Financial Statements, to establish more detailed information about the value of this type of IA in Section 1 Intangible Assets, line code 060, it is necessary to decrypt the information for this sub-account separately. Therefore, the Notes to the Annual Financial Statements will separately show the software information: balance at the beginning of the year; received in a year; revaluation (markup +, markdown -); left in a year; depreciation accrued for the year; impairment losses for the year; other changes for the year; balance at the end of the year. Such separation will improve the management of the accounting information about the entity's software, namely: to track their value; set deadlines for program updates; to prevent the use of programs by aggressor countries; avoid using unlicensed software. In general, this will increase the level of control over this type of IA.

A further problematic issue in accounting for IA is the inconsistency in reflecting Goodwill in the Plan of Accounts and Reporting, which requires the amendment of Section 1 of the Notes to the Annual Financial Statements. The name of Form № 5 of section 1 «Intangible Assets» section needs to be changed, because this section discloses information about the IAs, according to the Accounts Plan, are accounted under Account 12 «Intangible Assets» and Goodwill, which is recorded on another account 19 «Goodwill». Also, it should be noted that the methodological principles of accounting and goodwill information and accounting disclosure in the financial statements are separately regulated by different standards, namely: PAS 8 «Intangible assets» and PAS 19 «Business Combinations», which confirms the need to clarify the title of Section 1 in this revision, «Intangible assets and goodwill».

Some questions also need clarification regarding how goodwill is recorded in accounting and reporting. In accordance with PAS 19 «Business Combinations», goodwill is the excess of the cost of the acquisition over the buyer's fair value of the acquired identifiable assets, liabilities and contingent liabilities at the acquisition date. This kind of goodwill arises upon the acquisition and disclosure of business combinations and / or their activities. There is also «internal goodwill», which is described in writings by several scholars, such as Travin (2010), Umantsiv (2006), Holov et al. (2013), etc., with which we agree. Tearney (1973) noted that intangible values such as goodwill are the motivating factor in the acquisition decision. Goodwill indicates the company's over-profitability. He emphasizes that all intangible assets are acquired in business combinations, which are designated as goodwill have to be identified, valued and disclosed, and not to be stated in the same amount in the financial statements.

According to Ping and Bao (2014), goodwill should be periodically assessed during the normal business period to maintain and improve the commercial well-being of enterprises, not only when assets are transferred or invested as shares. We agree with the authors and consider it is necessary to keep records of internal goodwill with the establishment of factors of its occurrence and the separation of components, which will allow to identify the strengths of the company in its activities, as well as, if necessary, the sale. Internal goodwill must be reflected not only in management but also in the financial accounting of enterprises. These include self-created trademarks, business connections, intellectual capital, etc. that can be accounted for in the subaccount 192 «Internal Goodwill». This approach requires the amendment of Section 1 of the Notes to the Annual Financial Statements to include the additional line 095 «Internal Goodwill». The integration of management and financial accounting has several advantages and is revealed using a single informational database. It will save time for transferring data from the 
management accounting system to the financial accounting system, accelerate the formation of indicators in the financial statements, will allow to quickly use information about the movement, status, effectiveness of $I A$ and goodwill, etc. The formation of IA and goodwill indicators in management accounting by responsibility centres (hereinafter referred to as $\mathrm{RC}$ ) in internal management reporting will enhance the performance of information and control functions for this type of assets. The informational function is revealed by the accumulation of information on the selected $R C$ in the context of individual types of $I A$ about their status, movement, etc. The management accounting of the IA provides feedback information on the occurrence of deviations from the approved indicators. The control function reveals that with the help of management accounting IA it is possible to control the indicators given in the management reports in an operational mode at the RC enterprise. When deviations from the planned budget are detected, the reasons for the deviations for timely response and taking appropriate measures are established. In an industrial enterprise, it is possible to distinguish such RC and their structural subdivisions, which are shown in Table 2.

Table 2. Responsibility Centres for Industrial Enterprise

\begin{tabular}{|c|c|c|c|}
\hline \\
\hline $\mathrm{RC}$ & Subdivisions of RC & $\mathrm{RC}$ & Subdivisions of RC \\
\hline \multirow[b]{2}{*}{$\begin{array}{l}\text { 1. Apparatus } \\
\text { Management }\end{array}$} & \multirow{2}{*}{$\begin{array}{l}\text { 1.1. Management (Chairman of } \\
\text { the Board, Director, Deputy } \\
\text { Directors) } \\
\text { 1.2. Finance Department } \\
\text { 1.3. Planning and Economic } \\
\text { Department } \\
\text { 1.4. Accounts Department: } \\
\text { 1.4.1.Department of Financial } \\
\text { Accounting and Tax Settlements } \\
\text { 1.4.2. Management accounting } \\
\text { Department }\end{array}$} & $\begin{array}{l}\text { 5. Production and } \\
\text { quality control } \\
\text { Department }\end{array}$ & $\begin{array}{l}\text { 5.1. Production Department } \\
\text { 5.2. Product quality control } \\
\text { Department }\end{array}$ \\
\hline & & $\begin{array}{l}\text { 6.Production } \\
\text { workshops }\end{array}$ & $\begin{array}{l}\text { 6.1. Production workshop } 1 \\
\text { 6.2. Production workshop } 2 \\
\text { etc. }\end{array}$ \\
\hline $\begin{array}{l}\text { 2. Commercial } \\
\text { Department }\end{array}$ & $\begin{array}{l}\text { 2.1. Supply Department } \\
\text { 2.2. Marketing Department } \\
\text { 2.3. Sales Department }\end{array}$ & 7. Warehousing & $\begin{array}{l}\text { 7.1. Storage of materials } \\
\text { 7.2.Storage of finished products }\end{array}$ \\
\hline \begin{tabular}{|c|}
$\begin{array}{c}\text { 3. Human Resources } \\
\text { Department }\end{array}$ \\
\end{tabular} & & 8. Store & $\begin{array}{l}\text { 8.1. Store } 1 \\
\text { 8.2. Store } 2 \\
\end{array}$ \\
\hline 4.Legal Department & & $\begin{array}{l}\text { 9. Secondary } \\
\text { households }\end{array}$ & $\begin{array}{l}\text { 9.1. Mechanical workshop } \\
\text { 9.2. Boiler room } \\
\text { 9.3. Transportation department }\end{array}$ \\
\hline
\end{tabular}

Source: Compiled by the authors.

The suggested approach to the formation of management reports based on information on IA across all RC will allow consolidating and summarizing information about IA for the required period. At the end of the reporting period, $\mathrm{RC}$ executives formulate internal reports, considering the movements of IA by RC divisions and submit them to the Management Accounting Department.

The Management Accounting Department collects, compares the planned and actual indicators and creates a consolidated document on the enterprise, which reflects the movement of the IA across all CR in general. The form of internal management register of cash flows in respect of the IA, shown in the example of RC «Apparatus Management», based on the Notes to the Annual Financial Statements, may be as given in (Table 3). 
Table 3. Report on IA and Goodwill of RC «Apparatus Management»

\begin{tabular}{|c|c|c|c|c|c|c|c|c|c|c|c|c|c|c|c|c|c|c|c|}
\hline \multirow{3}{*}{$\begin{array}{c}\text { Intangible } \\
\text { Assets } \\
\text { Groups / } \\
\text { Subaccou } \\
\text { nt № }\end{array}$} & \multirow{3}{*}{$\begin{array}{l}\text { Name / Analytical } \\
\text { account number }\end{array}$} & \multirow{3}{*}{ 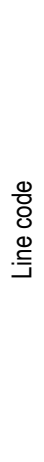 } & \multicolumn{2}{|c|}{$\begin{array}{l}\text { Residue at } \\
\text { the } \\
\text { beginning } \\
\text { of the } \\
\text { period }\end{array}$} & \multirow{3}{*}{ 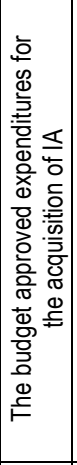 } & \multirow{3}{*}{ 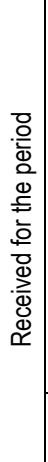 } & \multirow{2}{*}{\multicolumn{2}{|c|}{ 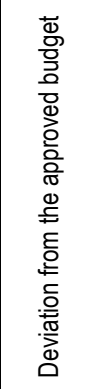 }} & \multirow{3}{*}{ 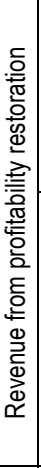 } & \multicolumn{2}{|c|}{$\begin{array}{l}\text { Revalua } \\
\text { tion } \\
\text { (markup } \\
+ \\
\text { markdo } \\
\text { wn -) } \\
\end{array}$} & \multicolumn{2}{|c|}{$\begin{array}{l}\text { Left for } \\
\text { the } \\
\text { period }\end{array}$} & \multirow{3}{*}{ 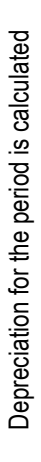 } & \multirow{3}{*}{ 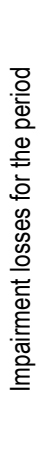 } & \multicolumn{2}{|c|}{$\begin{array}{l}\text { Other } \\
\text { changes } \\
\text { for the } \\
\text { period }\end{array}$} & \multicolumn{2}{|c|}{$\begin{array}{l}\text { Residue } \\
\text { at end } \\
\text { of the } \\
\text { period }\end{array}$} \\
\hline & & & \multirow{2}{*}{ 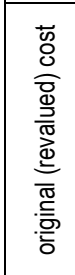 } & \multirow{2}{*}{ 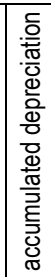 } & & & & & & \multirow{2}{*}{ 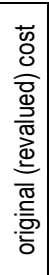 } & \multirow{2}{*}{ 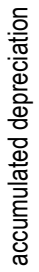 } & \multirow{2}{*}{ 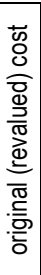 } & \multirow{2}{*}{ 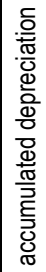 } & & & \multirow{2}{*}{ 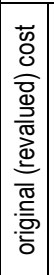 } & \multirow{2}{*}{ 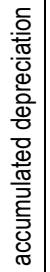 } & \multirow{2}{*}{ 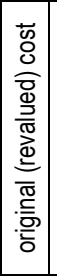 } & \multirow{2}{*}{ 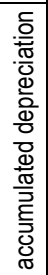 } \\
\hline & & & & & & & $\begin{array}{c}\|+ \\
» \\
\end{array}$ & 《- & & & & & & & & & & & \\
\hline$f$ & $\mathrm{~m}$ & $f$ & $f$ & $f$ & $\mathrm{~m}$ & $f$ & $\mathrm{~m}$ & $\mathrm{~m}$ & $f^{*}$ & $f$ & $f$ & $f$ & $f$ & $f$ & $f$ & $f$ & $f$ & $f$ & $f$ \\
\hline $\begin{array}{l}\text { Rights to } \\
\text { use } \\
\text { natural } \\
\text { resources } \\
/ 121\end{array}$ & $\begin{array}{l}\text { the right to use the } \\
\text { subsoil, other natural } \\
\text { resources / 121.1, } \\
\text { the right to use } \\
\text { geological and other } \\
\text { information about the } \\
\text { environment / 121. } 2\end{array}$ & 010 & & & & & & & & & & & & & & & & & \\
\hline $\begin{array}{c}\text { Property } \\
\text { rights / } \\
122\end{array}$ & $\begin{array}{l}\text { the right to use the } \\
\text { land / } 122.1 \text {, } \\
\text { the right to use the } \\
\text { building / } 122.2 \text {, } \\
\text { the right to lease } \\
\text { premises } 122.3\end{array}$ & 020 & & & & & & & & & & & & & & & & & \\
\hline $\begin{array}{c}\text { Commerci } \\
\text { al } \\
\text { Designati } \\
\text { on Rights } \\
\text { / } 123\end{array}$ & $\begin{array}{c}\text { the right on } \\
\text { trademarks (marks for } \\
\text { goods and services) } \\
123.1, \text { the right on } \\
\text { commercial (trade) } \\
\text { names } 123.2 \\
\end{array}$ & 030 & & & & & & & & & & & & & & & & & \\
\hline $\begin{array}{c}\text { Industrial } \\
\text { Property } \\
\text { Rights / } \\
124\end{array}$ & $\begin{array}{c}\text { right on inventions, } \\
\text { utility models / 124. } 1 \text {, } \\
\text { the right on industrial } \\
\text { designs / 124. 2, } \\
\text { right on plant varieties, } \\
\text { animal breeds / 124.3, } \\
\text { the right on the } \\
\text { arrangement } \\
\text { (topography) of } \\
\text { integrated circuits / } \\
124.4 \text {, } \\
\text { the right on trade } \\
\text { secrets, including } \\
\text { know-how, protection } \\
\text { against unfair } \\
\text { competition / 124.5 }\end{array}$ & 040 & & & & & & & & & & & & & & & & & \\
\hline
\end{tabular}


Continued Table 3

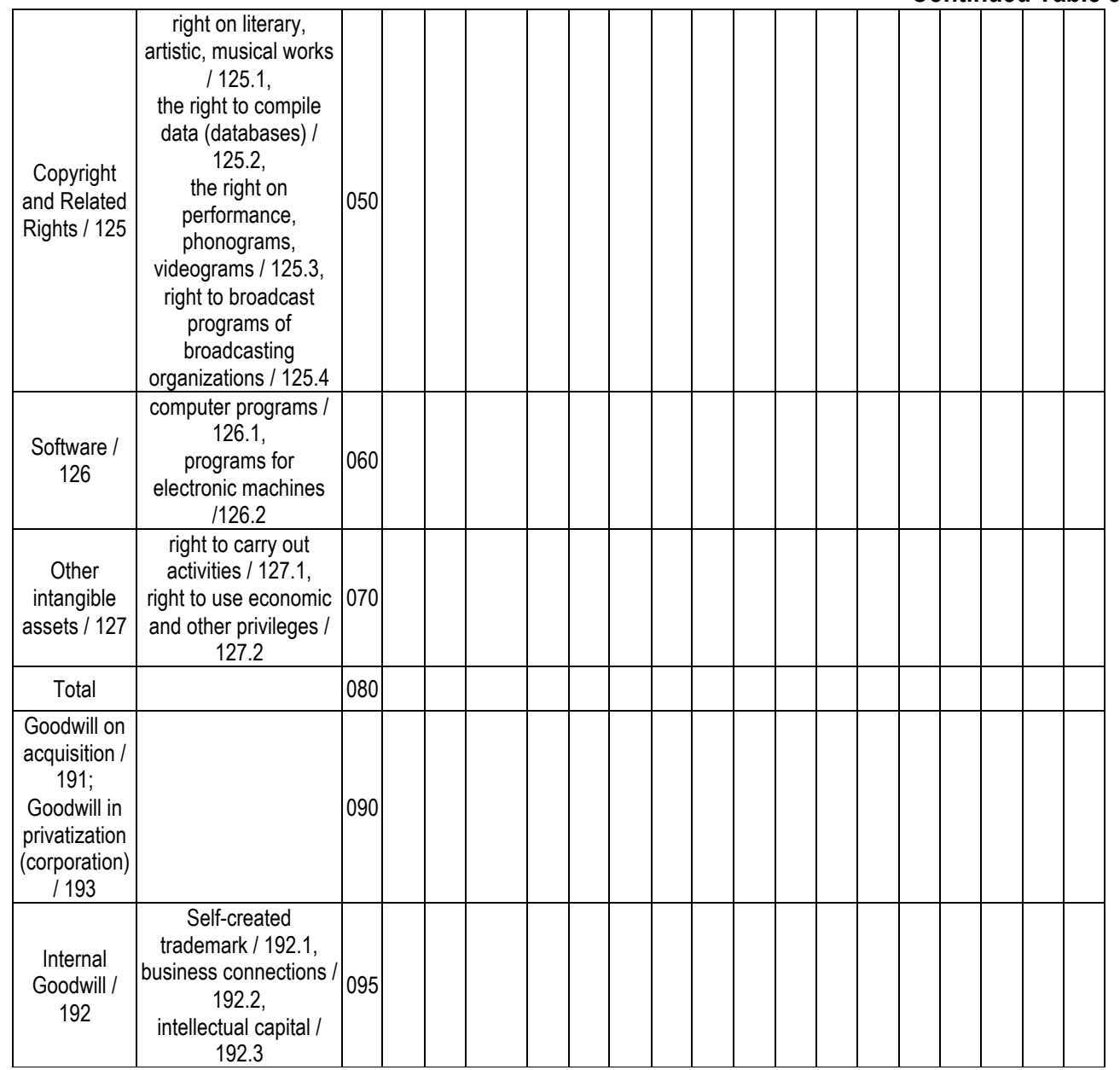

$\mathrm{f}$ - the graph is displayed in $\mathrm{f}$ №5 «Notes to the Annual Financial Statements»; $f$ * - the graph is suggested to be added to f. № 5 «Notes to the Annual Financial Statements»; $m$ - the graph shows the indicators needed for management accounting necessities

The internal management reporting form gives the name and number of the analytical account to the relevant subaccount, which reflects the type of assets available at the enterprise.

The surplus or deficit of cash spent on the acquisition of the IA is determined by comparing the planned and actual variances, which are gradually added throughout the period. The consolidated form of internal management reporting is formed based on the generalization of information on all divisions of the respective RC. To improve the management of the IA, it is necessary to distinguish the assets of the IA that are not reflected in PAS 8 but should be valued by the company because they affect its additional value. They can be customer lists, extra-contractual relationships with clients; contracts for advertising, construction, management, supply; non-compete agreements; confidentiality agreements; franchise agreements; contractual or non-contractual rights on formulas, projects, recipes; titles and titles of publications; IA under development; broadcasting rights; information resources, including forecasts, 
estimates, technical data; rationalization proposals; trained workers in the relevant direction; favourable employment contracts; favourable insurance contracts; technical libraries and newspaper repositories; personal goodwill. Isolating objects can be assigned to the internal goodwill.

Through the use of the suggested internal reporting form, which is based on f. № 5 «Notes to the Annual Financial Reporting», with the inclusion of additional indicators for management accounting, the management system can identify IA at the relevant $\mathrm{RC}$, which enables the management service to receive information both at the $\mathrm{RC}$ and at their departments, at different periods, to have indicators throughout the enterprise, to control the amount, direction, deviation of planned and actual expenses at the receipt of IA. With this form of internal reporting, it will be easy to prepare financial statements at the end of the financial year. With the introduction of internal management reporting on IA at enterprises, there is a need to implement an integrated, multifunctional automated system that will provide synchronous generation of the necessary indicators that will be reflected in financial and management accounting. Another problematic issue is the reflection of surpluses or shortages of IA in accounting. In the Appendix to the Methodological Recommendations for Accounting of Intangible Assets, approved by the Order of the MOF of 16.11.2009 №1327 (hereinafter Methodical Recommendations №1327) the procedure for accounting only for the surplus of IA according to the inventory results was disclosed. The procedure for the accounting of IA shortages in PAS 8 and Methodological Recommendations №1327 is not disclosed. In some literature, it is recommended to reflect the shortage of IA in a similar way to non-current assets disposal operations. Therefore, the activities of economic entities in the formation of accounting correspondence are guided by the paragraph 30 of the Annex to Methodological Recommendations №1327, which reflects the operation to eliminate the IA using the subaccount 976 «Non-current assets write-off». To account the shortage of IA, it is necessary to open an additional sub-account 973 to reflect the loss of non-current assets and call it «Shortage of non-current assets». This subaccount will be similar to the subaccount 947 «Impairment and loss of depreciation», but, on the contrary, it will be used to account the transactions with non-current assets. The write-off of the IA shortage from the enterprise's balance sheet will be reflected by the following correspondence: the amount of accumulated depreciation due to lack of IA Debit 133 - Credit 12; the residual value for the shortage of IA objects was written off Debit 973 - Credit 12. It is necessary to amend the Instruction on the Application of the Plan of Accounts of Assets, Capital, Liabilities and Business Transactions of Enterprises and Organizations № 291 and to make additional correspondence with clauses 14.4 and 14.5 to Section 3 «Accounting of Intangible Assets by Inventory Results» of the Appendix to Methodological Recommendations №1327. It should be emphasized that in Methodical Recommendations №1327 it will be incorrect to reflect the lack of IA with the correspondence of Debit 973 - Credit 12. The reasoning behind this statement is that account 94 should reflect shortages of current assets and for identified shortages of non-current assets, account 97 should be used to account the cost of investment activities. One of the new forms of reporting for domestic companies in the Management Report, which became a practice of foreign companies a long time ago. This report contains financial and non-financial information that characterizes the status and prospects of the enterprise's development and highlights the major risks and uncertainties of its operations. The Management Report $t$ is submitted together with the financial statements and the consolidated financial statements in the manner and within the time limits prescribed by law. It aims to supplement the annual financial statements with the necessary information and is a kind of «business card» of the enterprise.

It is not correct to assign the Management Report to the Financial Reporting. Confirmation that this report should not be included in the financial reporting is revealed in the following:

1. According to Art. 1, Section 1 of the Law of Ukraine "On Accounting and Financial Reporting» financial reporting is the financial reporting that contains information about the financial condition and the results of the enterprise operations. Unlike the management report, this contains not only financial but also non-financial indicators. 
2. According the standards of NPSA 1 «General Requirements for Financial Reporting» in Section 2 Composition and elements of financial reporting, it is stated that the financial reporting consists of balance sheet (statement of financial condition) (hereinafter referred to as the balance sheet), the report on the financial results (statement of comprehensive income) (hereinafter - the statement of financial results), the statement of cash flows, the statement of equity and the notes to the financial statements. Therefore, this list does not include the Management Report.

3. In the clause 2 of the Resolution of the Cabinet of Ministers of Ukraine «On approval of the Financial Reporting Order» of 28.02.2000 №419, it is defined that the management report is submitted together with the annual financial reporting, but the submission of this report to the State Fiscal Service and the State Statistics Committee is not indicated (except in some cases). In accordance with clause 2 of Order №419, the management report, together with other reports, must be published on the company's website or website.

4. The standardized form of the management report is not disclosed, so it is prepared according to the given recommendations in an arbitrary form. Unlike financial reporting, which is regulated.

Therefore, given the above arguments, it can be argued that the Management Report does not belong to financial reporting.

Regarding the issue of attribution, the management report to managerial reporting, it should be noted that it does not disclose in detail all the management information, because such openness can damage the activity of the enterprise and can be negatively used by competitors. Also, as noted, this report is disclosable and managerial reporting is confidential and cannot be classified as such. Therefore, the Management Report should be considered as a supplement to financial reporting.

The information that companies and organizations are advised to disclose in the management report is contained in the MOF Order «On Approval of the Methodological Recommendations for Preparation of the Management Report» № 982 of 07.12 .2018 (hereinafter Methodical Recommendations № 982). In clause 2 of Section 2 of these recommendations, there are 10 directions according to which it is recommended to systematize the reporting information. We will pay special attention to the clause 7 «Research and Innovation» and the clause 10 «Corporate Governance (consists of companies - issuers of securities whose securities are admitted to trading on the stock exchanges or in respect of securities of which a public offering is made)». According to clause 3 of Section 3 of this recommendation, the list of directions and indicators that an entity may disclose in a report is not exhaustive. Therefore, an entity may also disclose other information that it deems to be important. Given the fact that intangible assets occupy key positions in the global economy today, there is a need to present their constituent in this report. Therefore, in the clause 7 «Research and Innovation», it is advised to disclose information about the IA and, if available, the Goodwill contained in the Notes to the Annual Financial Statements in the dynamics for 5 - 10 years according to the IA groups. The disclosure of this information will not impair the entity's operations, as the Notes to the Annual Financial Statements are disclosed. In general, it is possible to compare the shares of tangible and intangible assets in a specific weight over a certain period and to identify tendencies. The study period may be set by the enterprise, but the clearest picture can be obtained by examining the data from the time the company was created. The wording of clause 7 of Section 3 of Methodological Recommendation №982 allows businesses to provide general information on research, innovation and development, as well as the overall cost of such activities. It should be noted that the previous proposals of the Methodological Board on Accounting raised the question of the information disclosure from which inventions, in terms of their types, what revenue should be received by the enterprise. Displaying such indicators in this report will violate the business secretly and its owners and administration will not allow such information to be disclosed. Therefore, the information in this area should not be given out in the context of individual species, but by the enterprise, without specifying. 
In clause 10 of Section 3 "Corporate Governance», it is recommended to provide information on several positions. Let us pay attention to the paragraph 8 «Perspectives of development and improvement of corporate governance» and paragraph 9 «enterprise policies regarding administrative, managerial and supervisory bodies of the enterprise (requirements for age, gender, education, professional experience, management personnel, the goals of its policies and results in the reporting period, etc.)», which indicate the importance of the development of intellectual capital of the company.

The development of the intellectual capital of the company should be carried out through training of administrative and managerial personnel, improvement of their professional qualification, which should meet the modern needs of economy and activity of the company in the part of production which is being modernized and updated. Investing in the training and development of all employees of the company reduces the risk of damage to new equipment and technologies by increasing their professional operation. Investing in various training programs both in Ukraine and abroad will allow training administrative, managerial staff and workers of working specialities and will teach them the quality management and the required level of work performance. Disclosure of information of the total number of administrative, managerial employees who work at the enterprise, have full higher education, basic higher education, employees with scientific degrees and academic titles will allow estimating the level of their professional training and will promote its improvement. Coverage of areas of cooperation with the higher educational institutions, which carry out training of specialized specialists, namely: conducting training and professional development of employees; internships for teachers of higher education institutions based on enterprises; preparation of students in the necessary specialities; student internships at enterprises; employment of the graduates. Determining the priority areas of work with personnel that can be revealed through the protection of investments in human capital, the implementation of training projects to provide the company with qualified staff, the continuation of the formation of managerial staff reserve, the introduction of several online programs for training employees, the implementation of projects for staff evaluation and more. All information contained in the Management Report can be further illustrated in the form of illustrations, graphs, diagrams and more. This type of reporting should be accessible to different levels of users. It should convey the overall impression of the company and its strategy; in general, it should strengthen its brand. Each company should develop its report form, considering the specific features of the business that will help attract clients and investors.

Conclusions. For state statistical observations, the Methodological Provisions №417 should be amended by isolating the IA into a separate group. This will allow conducting a comprehensive analysis of IAs (by industry, region, etc.) to identify the tendencies of their impact on the economy. For the software accounting (computer programs, programs for electronic computers) it is advisable to isolate the subaccount 126 «Software». Respectively, in the Notes to the Annual Financial Statements, the details of the value of the software in Section 1 «Intangible Assets» need to be separately decrypted for this subaccount. In order to reconcile goodwill in the Plan of Accounts and Reporting, it is necessary to amend the title of Section 1 «Intangible Assets» of form №5 «Notes to the Annual Financial Statements» and set it out in the following wording: «Intangible Assets and Goodwill». This change will not contradict the requirements of PAS.

Accounting of the internal goodwill with the establishment of factors of its occurrence, the separation of its components, it is advisable to carry it out on the subaccount 192 «Internal Goodwill», which will identify the strengths of the company during its operations, as well as, if necessary, when selling. Internal goodwill must be reflected not only in managerial but also in the financial accounting of enterprises and its reporting, in form №5 of «Notes to the Annual Financial Statements».

The proposed form of internal management reporting should be used to maintain the management accounting for the IA and goodwill, which is based on form №5 of «Notes to the Annual Financial Statements». This form includes additional indicators that allow the management system to identify the 
IAs at the relevant RCs and their subdivisions, at different periods, to have indicators throughout the enterprise, to control the volume, direction, deviations of planned and actual expenses at the receipt of IAs. The approach of the formation of the internal management reporting indicators by the RCs will allow to objectively evaluate the potential of the NMAs owned by the enterprise, will help to strengthen its position in the competitive environment. The improvement of the IA shortage accounting will be facilitated by the opening of the proposed subaccount 973 «Shortages of non-current assets». The procedure for the accounting of the IA shortages using the subaccount 973 is proposed to be disclosed in the Appendix to Methodological Recommendations №1327. The management report is not a part of the financial or managerial reporting. It should be considered as a supplement to financial reporting.

In the clause 7 «Research and Innovation» of the management report it is required to disclose the information about the IA and, if available, about goodwill, and in the clause 10, "Corporate Governance», to provide the information aimed at the development of the intellectual capital. The proposals mentioned above will help improve the accounting of IAs at the domestic enterprises, as well as reconcile PAS with IAS and can be used in foreign practice.

Author Contributions: conceptualization, Z.-M. Z. and V. Y.; methodology, Z.-M. Z. and V. Y.; formal analysis, Z.-M. Z. and V. Y.; investigation, Z.-M. Z. and V. Y.; resources, Z.-M. Z. and V. Y.; data curation, Z.-M. Z. and V. Y.; writing-original draft preparation, Z.-M. Z. and V. Y.; writing-review and editing, Z.-M. Z. and V. Y.; visualization, Z.-M. Z. and V. Y.; supervision, Z.-M. Z. and V. Y.; project administration, Z.-M. Z. and V. Y.; funding acquisition, Z.-M. Z.

Funding: the research was funded at the expense of the implementation of the state budget theme «Concept of development of management accounting in multinational corporations», the term of execution 2017 - 2019, registration number 0117 U000411.

\section{References}

Best global brands. Interbrand. (2018). Retrieved from https://www.interbrand.com/best-brands/best-global-brands/2018/

Delios, A., \& Beamish, P. W. (2001). Survival and profitability: the roles of experience and intangible assets in foreign subsidiary performance. Retrieved from http://citeseerx.ist.psu.edu/viewdoc/download?doi=10.1.1.203.3717\&rep=rep1\&type=pdf

Holov, S. F., Kostiuchenko, V. M., \& Kulaha, O. M. (2013). Transformatsiia finansovoi zvitnosti ukrainskykh pidpryiemstv u finansovu zvitnist za mizhnarodnymy standartamy [Transformation of the financial statements of Ukrainian enterprises into financial statements according to international standards]. Kyiv: FPBAU [in Ukrainian]

Horovyi, D.A. (2016). Comparison analysis of enterprise intangible assets structure in Ukraine and over the world. Marketing and Management of Innovations, 4, 256-268.

Kaplan, R. S., \& Norton, D. P. (2004). The strategy map: guide to aligning intangible assets. Strategy \& Leadership, 32(5), $10-17$.

Methodological provisions on the use of financial statements for the purposes of enterprise statistics: from December 31 No. 417]. Retrieved from https:// zakon.rada.gov.ua/rada/show/v0027832-15

Metodychni rekomendatsii z bukhhalterskoho obliku nematerialnykh aktyviv: zatverdzheno nakazom MFU vid 16.11.2009r. № 1327 [Methodical recommendations on accounting for intangible assets: from November 16th 2009, No. 1327]. Retrieved from https:// zakon.rada.gov.ua/rada/show/en/v1327201-09 [in Ukrainian]

International Accounting Standard 38 Intangible assets: International document from 1st January 2012. Retrieved from http://zakon2.rada.gov.ua/laws/show/929_050/page2

Natsionalne polozhennia (standart) bukhhalterskoho obliku 1 «Zahalni vymohy do finansovoi zvitnosti»: zatverdzheno nakazom MFU vid 07.02.2013r. № 73. [National accounting standard 1 General requirements for financial statements: from 2 February 2013 , No. 73]. Retrieved from https://zakon.rada.gov.ua/laws/show/z0336-13 [in Ukrainian]

Ping, H. D., \& Bao, Di (2014). Valuating goodwill of cultural enterprises using wavelet neural network. International journal of uand e-Service. Science and Technology, Vol. 7, 4, pp. 147-158.

Polozhennia (standart) bukhhalterskoho obliku 8 «Nematerialni aktyvy»: zatverdzheno nakazom MFU vid 18.10.1999r. № 242. [National accounting standard 8 Intangible assets: from 18 $8^{\text {th }}$ October 1999, No. 242]. Retrieved from http:// zakon4.rada.gov.ua/laws/show/z0750-99/ [in Ukrainian]. 
Polozhennia (standart) bukhhalterskoho obliku 19 «Obiednannia pidpryiemstv»: zatverdzheno nakazom MFU vid 07.07.1999 r № 163 [National accounting standard 19 Business combinations: from July 7th 1999, No. 163]. Retrieved from http:// http://zakon4.rada.gov.ua/laws/show/z0750-99 [in Ukrainian].

Pro zatverdzhennia Metodychnykh rekomendatsii zi skladannia zvitu pro upravlinnia: zatverdzheno nakazom MFU vid 07.12.2018r. № 982 [On approval of the Guidelines for the preparation of the management report: from December $7^{\text {th }} 2018$, No 982]. Retrieved from https://zakon.rada.gov.ua/rada/show/v0982201-18 [in Ukrainian].

Stewart, T.A. (1997) Intellectual capital: the new wealth of organizations. Doubleday/Currency, New York.

Tearney, M.G. (1973). Accounting for Goodwill: a realistic approach, The Jourof Accountancy, July, pp. 41-45.

Travin, V. V. (2010). Osoblyvosti orhanizatsii bukhhalterskoho obliku vnutrishnoho hudvilu yak proiavu sotsialnoho kapitalu na mikroekonomichnomu rivni [Features of internal goodwill accounting as a manifestation of social capital at the microeconomic level]. Visnyk ZhDTU - ZhSTU Bulletin, 2 (52), 197-201[in Ukrainian].

Umantsiv, H. V. (2006). Vnutrishnii hudvil pidpryiemstva: ekonomichna pryroda, problemy otsinky ta obliku [Internal goodwill of the enterprise: economic nature, problems of valuation and accounting]. Bukhhalterskyi oblik $i$ audyt - Accounting and Auditing, 9, $20-23$ [in Ukrainian].

World Bank (2019). World Development Indicators 2019, World Bank. Retrieved from : https://data.worldbank.org/indicator.

3.-М. В. Задорожний, д.е.н., професор, Тернопільський національний економічний університет (Україна);

В. В. Ясишена, к.е.н., доцент, Тернопільський національний економічний університет (Україна) Проблеми обліку і звітності нематеріальних активів

У статті розглянуто погляди зарубіжних економістів щодо важливості впливу нематеріальних активів (HМА) та гудвілу на бізнес. Основною метою проведеного дослідження $\epsilon$ удосконалення $і$ розробка підходів до обліку НМА та гудвілу, їх відображення у фрінансовій і управлінській звітності. Систематизація літературних джерел і вивчення нормативних документів засвідчила, що існуе низка проблемних питань пов'язаних з відображенням в обліку і звітності HМА та гудвілу, які потребують розробки і уточнень. Актуальність вирішення цієї наукової проблеми полягає в тому, що через існування невирішених питань в обліку НМА та гудвілу, а також фформування показників у фрінансовій звітності відбувається значний розрив між методологією обліку цих активів і сучасними вимогами економіки. Запропоновано внести зміни в Методологічні положення № 417 шляхом виокремлення НМА в окрему групу для більш деталізованого державного статистичного спостереження за иими активами. Рекомендовано виокремити субрахунок для обліку програмного забезпечення з відображенням детальної інформації по даному субрахунку в Примітках до річної фінансової звітності. 3 метою узгодження відображення гудвілу у Плані рахунків $і$ звітності запропоновано викласти назву 1 Розділу Приміток до річної фінансової звітності у такій редакції «Нематеріальні активи та гудвіл». Рекомендовано вести облік внутрішнього гудвілу в управлінському і фрінансовому обліку з виокремленням окремого субрахунку із внесенням змін до 1 Розділу Приміток до річної фрінансової звітності у частині включення додаткового рядка 095 «Внутрішній гудвіл». Для ведення управлінського обліку НMA та гудвілу запропоновано використовувати форму внутрішньої управлінської звітності в основу, якої покладена ф.5 «Примітки до річної фрінансової звітності», що містить додаткові показники, які дозволяють системі управління ідентифрікувати НМА як за відповідними центрами відповідальності, так і за їх підрозділами, за різними періодами часу, контролювати обсяг, напрям, відхилення планових $i$ фактичних витрат при надходженні НМА тощо. Рекомендовано для обліку нестач НМА відкрити додатковий субрахунок з розкриттям в Додатку до Методичних рекомендацій № 1327 порядку обліку нестач HМА із використанням иього субрахунку. Обгрунтовано, що Звіт про управління необхідно вважати інфоормаційним доповненням до фрінансової звітності. В звіті про управління запропоновано розкривати інформацію про НМА і за наявності про гудвіл (внутрішній гудвіл), а також наводити інформацію направлену на розвиток інтелектуального капіталу.

Ключові слова: бренд внутрішній гудвіл, звіт про управління, ідентифікація, інтелектуальний капітал, нематеріальні активи (НMA), необоротні активи, облік, управлінська звітність, фінансова звітність.

Manuscript received: 03.06.2019.

(c) The author(s) 2019. This article is published with open access at Sumy State University. 